\title{
KUALITAS SPERMATOZOA AYAM KAMPUNG DAN AYAM ARAB DENGAN LAMA SIMPAN YANG BERBEDA PADA SUHU RUANG
}

\author{
Enike Dwi Kusumawati ${ }^{1}$, Aju Tjatur Nugroho Krinaningsih ${ }^{1}$, Aditia Umbu Kulli Walangara ${ }^{1}$ \\ ${ }^{1}$ Fakultas Peternakan, Universitas Kanjuruhan Malang \\ Email : destrykrisnan@gmail.com; enike@unikama.ac.id
}

\begin{abstract}
Abstrak
Penelitian ini dilaksanakan di Laboratorium Fakultas Peternakan Universitas Kanjuruhan Malang yang dimulai pada bulan Maret sampai dengan bulan Mei 2019. Tujuan dari penelitian ini adalah untuk mengetahui perbandingan kualitas spermatozoa semen Ayam Kampung dana yam Arab dengan lama simpan yang berbeda pada suhu ruang. Dalam penelitian ini materi yang digunakan semen ayam Kampung dan ayam Arab yang berasal dari dua ekor ayam kampung jantan dan 2 ekor ayam Arab jantan yang berumur 1,5 - 2 tahun yang memiliki bobot badan $\pm 2,5$ $\mathrm{kg}$ dan tiap ekornya ditampung 1 kali per hari dan dalam satu kali penampungan dilakukan 1 kali ejakulasi. Dengan metode uji laboratorium menggunakan Rancangan Acak Lengkap (Faktorial). Perlakuan penelitian yaitu lama simpan $0,1,2,3$, dan 4 jam. Setiap perlakuan diulang sebanyak sepuluh kali. Data yang diperoleh dianalisis mengunakan analisis ragam. Hasil analisa data menunjukkan bahwa perlakuan memberikan hasil tidak berpengaruh nyata $(\mathrm{P}<0.05)$ antara jenis semen, lama simpan, dan penyimpanan pada suhu ruang. Terhadap motilitas viabilitas dan abnormalitas spermatozoa pada suhu ruang dengan lama simpan yang berbeda. Motilitas spermatozoa yang masih layak untuk IB sampai lama simpan 4 jam Setelah 4 jam motilitas tersebut tidak layak untuk IB. Viabilias spermatozoa yang masih layak untuk IB sampai lama simpan 4 jam. Setelah 4 jam viabilitas tersebut tidak layak untuk IB. Abnormalitas spermatozoa yang masih layak untuk IB sampai lama simpan 4 jam. Setelah 4 jam abnormalitas tersebut tidak layak untuk IB. Kesimpulan pada penelitian ini adalah terdapat pengaruh lama simpan terhadap kualitas spermatozoa, Setelah 4 jam motilitas tidak layak untuk IB, setelah 4 jam viabilitas tersebut tidak layak untuk IB, setelah 4 jam abnormalitas tersebut tidak layak untuk IB.

Kata kunci: kualitas sperma, ayam kampung, ayam arab, lama simpan, suhu ruang
\end{abstract}

\begin{abstract}
This research was conducted at the Laboratory of the Faculty of Animal Husbandry, University of Kanjuruhan Malang, which began in March until May 2019. The purpose of this study was to study the quality of semen of Native chicken, Arabian chicken funds with long stored that produce in spaces. In this study, the material used was cement of native chickens and Arabic chickens which were requested from two male chickens and 2 male Arab chickens needed $1.5-2$ years that had a body weight of $\pm 2.5 \mathrm{~kg}$ and each tail was accommodated 1 time per day and in one shelter done 1 ejaculation. The laboratory test method uses a completely randomized design (factorial). The research treatment is storing time $0,1,2$, 3, and 4 hours. Each payment is repeated ten times. The data obtained were analyzed using analysis of variance. The results of data analysis showed that the treatment gave no significant effect $(\mathrm{P}<0.05)$ between types of cement, storage time, and storage at room temperature. Against the viability motility and abnormalities of spermatozoa at room temperature with different shelf life. Spermatozoa motility that is still feasible for IB for a long time to store 4 hours After 4 hours the motility is not feasible for IB. Viabilias spermatozoa which are still viable for IB for up to 4 hours. After 4 hours the viability is not feasible for IB. Spermatozoa abnormalities that are still feasible for IB up to 4 hours long save. After 4 hours the abnormality is not suitable for IB. The conclusion of this study is that there is an effect of shelf life on the quality of spermatozoa. After 4 hours motility is not feasible for IB, after 4 hours the viability is not feasible for all, after 4 hours the abnormality is not feasible for all. Keyword: sperm quality, native chicken, long stored
\end{abstract}

\section{Pendahuluan}

Ayam Kampung atau dikenal dengan sebutan ayam buras (bukan ras) merupakan unggas asli Indonesia yang kehidupannya sudah lekat dengan masyarakat. Karakteristik ayam Kampung sangat beragam, begitu pula sifat genetiknya, penyebaran sangat luas dan 


\section{Jurnal Sains Peternakan}

Volume 8 No. 1, Juni 2020, pp:41-56

ISSN 2579-4450

di jumpai di kota maupun desa dan memiliki potensih untuk di kembangkan. Untuk mendapatkan potensi yang baik tersebut maka dilakukan pencarian calon bibit unggul, selain didasarkan pada tampilan luarnya juga dapat dilakukan dengan konsep pemuliaan ternak (Darwati, 2000).

Ayam Arab merupakan ayam tipe petelur dan memiliki tingkat efisiensi baik pakan dan kemampuan memproduksi telur. Populasi ayam Arab pada umumnya masih dilakukan dengan cara alami begitu pun pada perkawinankawin, sehingga perbanyakan bibit masih terbatas untuk usaha komersial maupun keperluan penelitian. Keberadaan ayam Arab di Indonesia memiliki daya adaptasi yang tinggi pada iklim dan pejantannya diketahui memiliki libido yang tinggi, Iskandar dkk. (2006) dan Nataamijaya dkk. (2003) ayam Arab jantan dewasa memiliki karakteristik volume semen per ejakulasi dan gerakan massa spermatozoa yang baik, motilitas dan konsistensi spermatozoa tinggi, $\mathrm{pH}$ semen netral, dan persentase spermatozoa abnormal relatif rendah.

Inseminasi Buatan dapat dilakukan untuk mengatasi rendahnya produktivitas karena sifat memilih pasangan yang tinggi pada ayam Kampung dan ayam Arab adanya perbedaan tingkat umur, baik pada jantan maupun betina. Selain untuk meningkatkan produktivitas ayam Kampung dan ayam Arab jantan, (IB) juga bertujuan untuk mencegah penularan penyakit viral, penyakit bakteri, dan penyakit parasit. Sampai saat ini belum ada standar lama simpan semen ayam Kampung dana yam Arab pada suhu ruang tanpa mengunakan pengencer yang masih dapat mempertahankan kualitas spermatozoa.

\section{Materi Dan Metode}

Penelitian ini dilakukan bulan Maret sampai April 2019 bertempat di Laboratorium Terpadu Fakultas Peternakan Universitas Kanjuruhan Malang. Materi yang digunakan dalam penelitian ini adalah semen ayam Kampung dan ayam Arab yang berasal dari dua ekor ayam Kampung jantan dan 2 ekor ayam Arab jantan berumur 1,5 - 2 tahun yang memiliki bobot badan $\pm 2,5 \mathrm{~kg}$ dan tiap ekornya ditampung 2 kali per minggu dan dalam satu kali penampungan dilakukan 2 kali ejakulasi.

Metode yang digunakan dalam penelitian ini adalah penelitian laboratorium menggunakan Rancangan Acak Lengkap Faktorial. Yang terdiri dari factor jenis ayam (ayam kampung dan ayam arab) dan faktor lama simpan (0, 1, 2, 3, 4 jam) masing-masing diluang 10 kali ulangan.

\section{Prosedur Penelitian}

1. Penampungan Semen 


\section{Jurnal Sains Peternakan}

Volume 8 No. 1, Juni 2020, pp:41-56

ISSN 2579-4450

Dalam penelitian ini ada 2 metode penampungan semen yang digunakan dikoleksi per individu dengan menggunakan metode massage atau pengurutan pada bagian dorsal atau punggung ayam pejantan. Sebelum penampungan dimulai, bagian belakang ayam sekitar bibir dan bawah kloaka dibersihkan dengan kertas tissue yang telah dibasahi dengan $\mathrm{NaCl}$ fisiologis. Metode pengurutan menggunakan jemari tangan kanan mengusap punggung sampai pangkal ekor, diteruskan naik sampai ke ekornya. Tangan kanan menggenggam dan sedikit mengangkat pangkal ekor. Perabaan yang dilakukan adalah tekanan tertentu sehingga cairan bening dan diikuti cairan kental putih seperti susu keluar.

2. Evaluasi Kualitas Semen Segar meliputi

\section{Makros kopis}

1. Warna dan bau

2. Volume

3. Konsentrasi

4. $\mathrm{PH}$

5. Gerak massa

\section{Mikros kopis}

1. Presentase motilitas

2. Persentase viabilitas

3. Presentase abnormalitas

3. Penyimpanan Semen pada suhu ruang

Penyimpanan semen pada suhu ruang dilakukan setelah proses penampungan semen selesai dengan lama simpan 0, 1, 2, 3, 4 .

4. Evaluasi motilitas, viabilitas dan abnormalitas

a. Motilitas spermatozoa yaitu pergerakan spermatozoa yang pengukurannya menggunakan spermatozoa diatas gelas objek dan diamati pergerakannya di bawah mikroskop. Persentase motilitas spermatozoa dapat diamati dengan perbesaran $400 \mathrm{x}$.

$$
\text { Motilitas individu spermatozoa }=\frac{\Sigma \text { spermatozoa progresif }}{\sum \text { total spermatozoa }}
$$

b. Viabilitas spermatozoa merupakan salah satu indikator untuk menentukan baikburuknya kualitas semen, daya hidup semen segar unggas pada temperatur kamar dapat bertahan selama 30 menit semenjak diejakulasikan, penentuannya dengan membuat ulasan eosin (berwarna merah sebagai pewarna spermatozoa)- 


\section{Jurnal Sains Peternakan}

Volume 8 No. 1, Juni 2020, pp:41-56

ISSN 2579-4450

negrosin (berwarna biru sebagai background), kemudian dihitung dalam bentuk persentase antara sperma yang hidup dan mati.

Viabilitas $=\frac{\sum \text { spermatozoa hidup }}{\sum \text { total spermatozoa }}$

c. Abnormalitas spermatozoa yaitu dibedakan antara bentuk abnormalitas primer dan sekunder, bentuk abnormalitas primer berasal dari gangguan pada testis dan abnormalitas sekunder berasal dari kesalahan perlakuan setelah semen dikeluarkan dari testis (karena goncangan yang keras, dikeringkan terlalu cepat, dipanaskan terlalu tinggi, kesalahan dalam membuat preparat ulas.

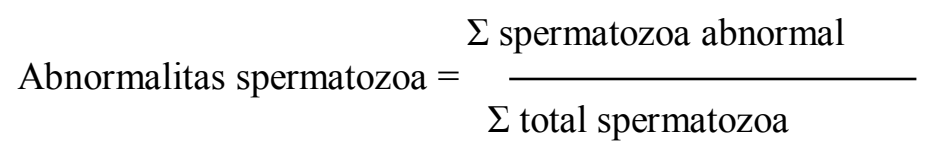

\section{Variabel yang diamati}

Variabel yang diamati dalam penelitian yaitu presentase motilitas, viabilitas dan abnormalitas spermatozoa.

\section{Analisis Data}

Data yang diperoleh dianalisis menggunakan varian. Apa bila terdapat pengaruh antara perlakuan maka dilanjutkan dengan uji beda nyata terkecil.

\section{Hasil Dan Pembahasan}

Berdasarkan hasil penelitian kualitas semen segar ayam Kampung dapat ditunjukkan pada tabel 1 .

Tabel 1. Kualitas Semen segar ayam

\begin{tabular}{llll}
\hline Pengamatan & Parameter & $\begin{array}{l}\text { Rataan ayam } \\
\text { Kampung }\end{array}$ & Rataan ayam Arab \\
\hline Makroskopis & Volume (ml) & $0,4 \pm 0,04$ & $0,04 \pm 0,05$ \\
& Bau & Khas & Khas \\
& Warna & Putih pekat & Krem \\
& Ph & $7,35 \pm 0,52$ & $7,2 \pm 0,42$ \\
& Konsistensi & Kental & Kental \\
Mikroskopis & Motilitas (\%) & $99 \pm 0,01 \%$ & $100 \pm 0$ \\
& Motilitas massa & Sangat bagus $(+++)$ & Sangat bagus $(+++)$ \\
& Viabilitas (\%) & $99,9 \pm 0,81$ & $99,7 \pm 0,67$ \\
& Konsentrasi & $3614,02 \pm 261,99$ & $2628,12 \pm 361,98$ \\
& $\left(10^{6}\right.$ spermatozoa $\left./ \mathrm{ml}\right)$ & & \\
& Abnormalitas (\%) & $1,3 \pm 0,13$ & $1,5 \pm 0,52$ \\
\hline
\end{tabular}




\section{Jurnal Sains Peternakan}

Volume 8 No. 1, Juni 2020, pp:41-56

ISSN 2579-4450

Berdasarkan evaluasi di atas menunjukkan bahwa kualitas semen segar ayam Kampung dana yam Arab yang diteliti sangat baik digunakan untuk keperluan program IB (Hafez and Hafez, 2008).

\section{Makroskopis}

\section{a. Volume}

Volume semen hasil penelitian ini setiap kali melakukan pemijatan mencapai sebesar 0,4 ml, pada ayam Kampung dan volume semen segar ayam Arab yang diperoleh pada penelitian ini adalah $0,04 \mathrm{ml}$. Untuk mengetahui volume semen dapat dipengaruhi karena adanya perbedaan bangsa, umur, nutrisi pakan, ukuran badan, dan frekuensi penampungan (Hafez and Hafez, 2008). Hal ini masih sesuai dengan Kartasudjana (2000) yang menyatakan bahwa volume semen ayam setiap kali ejakulasi berkisar antara 0,2-0,3 $\mathrm{ml}$. Volume semen yang dihasilkan dalam satu hari berbeda-beda pada tiap-tiap ternak.

\section{b. Warna}

Warna semen ayam Kampung yang dapat dihasilkan pada penelitian ini warna putih pekat dan warna semen ayam Arab yang diperoleh pada penelitian ini adalah warna krem, hasil semen pada penelitian ini dapat di katakan sangat normal dikarenakan tidak memiliki campuran warna lainnya yang menandakan adanya campuran kotoran. Hal ini sesuai dengan Rusdin (2006) yang mengemukakan bahwa warna semen yang normal adalah puth pekat dan krem. (Kartasudjana 2001) menyakan bahwa bila semen berwarna kemerahan adalah tandah bahwa semen terkontaminasi oleh darah segar, sedangkan apabila warna mendekati coklat dapat merupakan tanda bahwa darah yang mengontaminasi semen sudah mengalami dekonposisi.

\section{c. Konsistensi}

Pada penelitian ini hasil konsistensi semen ayam Kampung dana yam Arab yang diteliti adalah kental. Hal ini menunjukkan bahwa semen yang diamati pada hasil penelitian ini masih dalam taraf normal, (Lubis dkk., 2012). Bahwa semen yang menempel pada bagian tabung turun perlahan-lahan setelah tabung ditegakkan kembali menandakan bahwa semen tersebut mempunyai konsistensi yang kental, baik derajat kekentalannya hampir sama atau sedikit lebih kental dari susu, sedangkan yang jelek baik warna maupun kekentalannya sama dengan air kelapa.

\section{d. Derajat keasaman (pH)}

Peranan derajat keasaman sangat penting dikarnakan dapat mempengaruhi viabilitas spermatozoa. Apabila $\mathrm{pH}$ tinggi/rendah akan menyebabkan spermatozoa 


\section{Jurnal Sains Peternakan}

Volume 8 No. 1, Juni 2020, pp:41-56

ISSN $2579-4450$

mati. Derajat keasaman $\mathrm{pH}$ pada ayam Kampung adalah 7,35 $\pm 0,52$ dan derajat keasaman pH pada ayam Arab adalah 7,2 $\pm 0,42$. (2001) bahwa derajat keasaman (pH) semen umumnya berkisar 7,0土7,6. Tetapi $\mathrm{pH} 7$ pada semen yang diteliti termasuk pada kisaran pH netral, (Kartasudjana 2001) derajat keasaman semen pada umumnya pada kisaran $\mathrm{pH}$ netral.

\section{e. Bau}

Semen yang dihasilkan pada penelitian ini berbau khas sperma yaitu berbau amis khas sperma dan bau dari hewan itu sendiri. Apabila semen mengandung nanah dan mengeluarkan bau busuk disebabkan adanya infeksi organ atau saluran reproduksi hewan jantan (Kartasudjana 2001). Hal ini sesuai dengan para peneliti Suyadi dkk. (2012) Yang menyatakan bahwa semen dengan keadaan normal pada umumnya memiliki bau yang khas.

\section{Mikroskopis}

\section{a. Motilitas Massa}

Merupakan salah satu kriteria penentu kualitas sperma yang dilihat dari beberapa banyaknya spermatozoa motil progresif yang dibandingkan dengan seluruh semen yang ada dalam satu pandang mikroskop. Motilitas massa adalah pergerakan dari selsel spermatozoa yang secara bersama-sama membentuk gelombang. Semakin tinggi skala gerakan atau motilitas massa, maka kualitas sperma semakin baik dan ditandai dengan $(+++)$, (Tambing, dkk.,2003). Pamungkas, dkk.,(2008) bahwa, kriteria penilaian motilitas massa dapat dilakukan dengan melihat aktifitas gerakan yang ditandai dengan gelombang dimana cepat berpindah mendapat nilai +++ , sedang mendapat nilai ++ dan kurang dengan nilai + .

\section{b. Motilitas individu}

Berdasarkan hasil evaluasi semen Segar ayam Kampung dan Ayam Arab dapat diketahui bahwa semen dalam penelitian ini mempunyai motilitas yang baik. Ditunjukkan dengan persentase motilitas spermatozoa ayam Kampung sebesar $99 \pm 0,01 \%$ dan ayam Arab sebesar $100 \pm 0,00 \%$, sehingga dapat diproses lebih lanjut untuk keperluan IB, Zenichiro, dkk (2002) semen segar harus memiliki motilitas $\geq$ $70 \%$ agar dapat diproses lebih lanjut menjadi semen beku untuk keperluan IB.

\section{c. Viabilitas (Persentase Hidup Spermatozoa)}

Persentase viabilitas semen ayam Kampung pada penelitian ini adalah

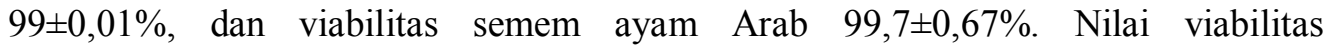




\section{Jurnal Sains Peternakan}

Volume 8 No. 1, Juni 2020, pp:41-56

ISSN 2579-4450

spermatozoa penelitian ini lebih besar dibandingkan laporan penelitian semen Ayam

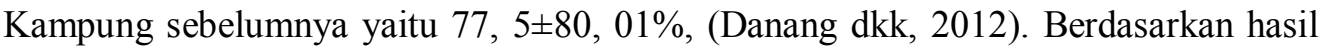
evaluasi semen segar ayam dapat diketahui bahwa semen dalam penelitian ini menmpunyai kualitas yang baik sehingga semen ini dapat diproses lebih lanjut. Hal ini sesuai dengan pendapat Hafez and Hafez (2008) menyatakan bahwa salah satu standar minimum bagi motilitas semen untuk proses lebih lanjut adalah $70 \%$.

\section{d. Konsentrasi}

Nilai konsentrasi pada kandungan sperma dalam $1 \mathrm{ml}$ merupakan salah satu indikator kualitas semen yang sangat berguna untuk menentukan jumlah betina yang dapat di IB, dalam penelitian ini sepen yang diperoleh pada ayam Kampung adalah $13697 \pm 1369,7 \%$, dan ayam Arab 2628,12 $\pm 361,98 \%$, juta sel $/ \mathrm{ml}$. Konsentrasi semen dipengaruhi oleh frekuensi penampungan semen, libido, pakan, suhu, dan musim. Konsentrasi spermatozoa merupakan jumlah spermatozoa per $\mathrm{ml}$ semen (Khairi dkk.,2014). Kekentalan atau konsitensi semen akan meningkat seiring dengan meningkatnya konsentrasi spermatozoa.

\section{e. Abnormalitas}

Persentase sperma abnormalitas ayam Kampung pada penelitian ini adalah $1,3 \pm 0,13, \%$ dan spermatozoa abnormalitas pada ayam Arab 1,5 $\pm 0,52 \%$ berdasarkan hasil penelitian ini, jika dibandingkan dengan hasil penelitian sebelumnya maka hasil penelitian persentase sperma abnormalitas ini sangat kecil. sesuai dengan standar IB, Kartasudjana (2001), semen untuk keperluan IB sebaiknya tidak mengandung sperma abnormal lebih dari $20 \%$.

\section{Motilitas}

a. Motilitas spermatozoa dengan jenis semen yang berbeda pada suhu ruang dengan lama simpan yang berbeda.

Hasil analisa data menunjukkan tidak ada pengaruh yang nyata antara semen ayam Kampung dan ayam Arab terhadap motilitas spermatozoa yaitu ( $\mathrm{P}>0,05)$. Berdasarkan Gambar 1 menunjukkan rataan persentase motilitas pengencer spermatozoa tertinggi pada semen ayam Kampung yaitu sebesar 92, 36\% sedangkan semen ayam Arab yaitu sebesar 90, 22\%.

Motilitas spermatozoa dengan jenis semen yang berbeda di tampilkan pada Gambar 1. 


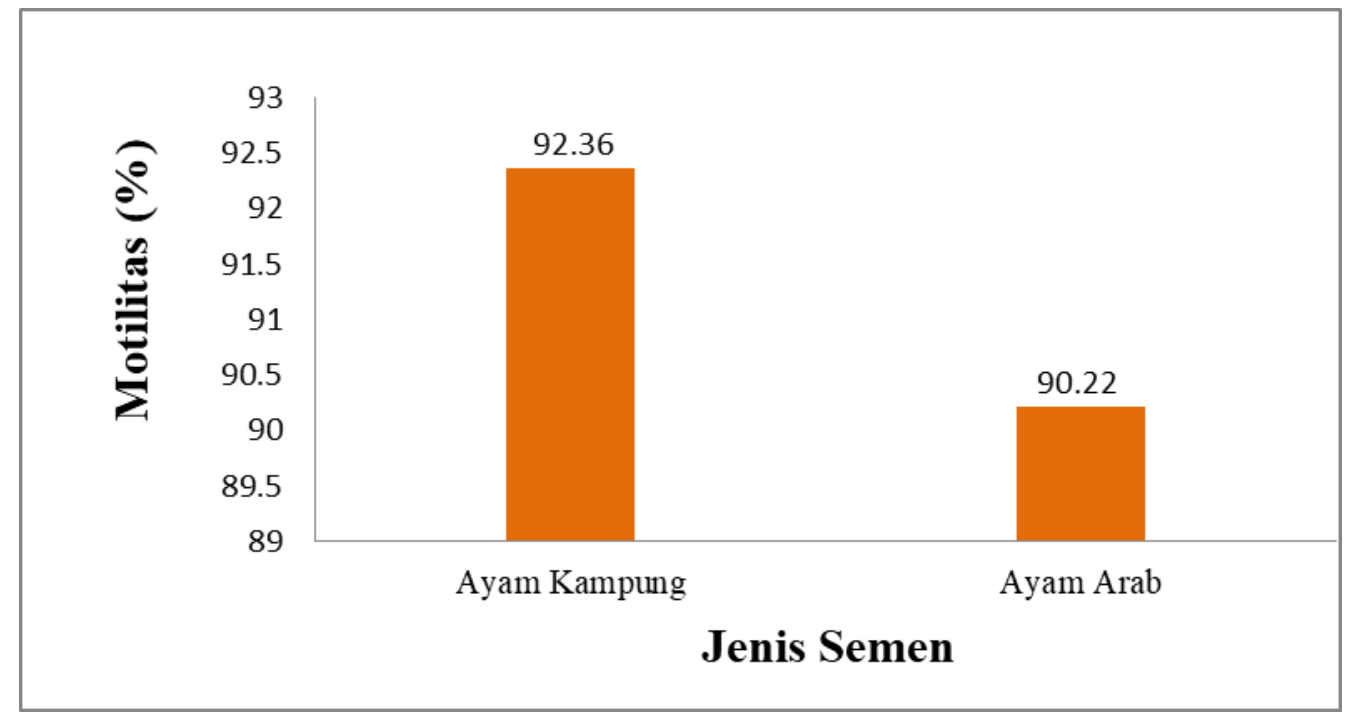

Gambar 1. Grafik motilitas spermatozoa mengunakan jenis semen yang berbeda.

Dari grafik jenis semen motilitas spermatozoa ayam dapat di simpulkan tidak ada pengaruh nyata antara spermatozoa ayam Kampung dan spermatozoa ayam Arab, tetapi masih memenuhu persyaratan untuk proses IB. Grafik juga menjunjukan semen ayam Kampung lebih dominan dibandingkan ayam Arab, dikarenakan ayam Kampung merupakan ayam lokal atau ayam asli Indonesia dan memiliki daya tahan tubuh yang lebih kuat dibanding ayam Arab yang dibawa dari luar Indonesia. Menurut Solihati dkk.(2006), kelebihan ayam Kampung memiliki daya adaptasi tinggi, tahan penyakit tertentu, dan pemeliharaannya mudah. Terjadinya penurunan motilitas semen dipengaruhi oleh faktor cuaca dan suhu ruang yang tidak stabil semakin lama waktu penyimpanan semen segar ayam Arab menyebabkan motilitas spermatozoa terus mengalami penurunan karena persediaan energi semakin terbatas, selama penyimpanan spermatozoa ini tetap melakukan aktivitas pergerakan dan metabolisme.

\section{b. Motilitas spermatozoa pada suhu ruang dengan lama simpan yang berbeda}

Hasil analisa data lama simpan tidak menunjukkan pengaruh yang nyata $(\mathrm{P}>0,05)$ terhadap motilitas spermatozoa. Tetapi dari Gambar 2 menunjukkan bahwa adanya penurunan motilitas dari jam ke 0-4. Semakin bertambah lama simpan maka motilitas juga semakin menurun. Hal ini disebabkan karena energi yang digunakan oleh spermatozoa untuk mempertahankan daya hidupnya semakin berkurang. Hal tersebut menyebabkan menurunnya motilitas spermatozoa. Hal tersebut sesuai dengan pendapat menurut Astuti dkk. (2014). 


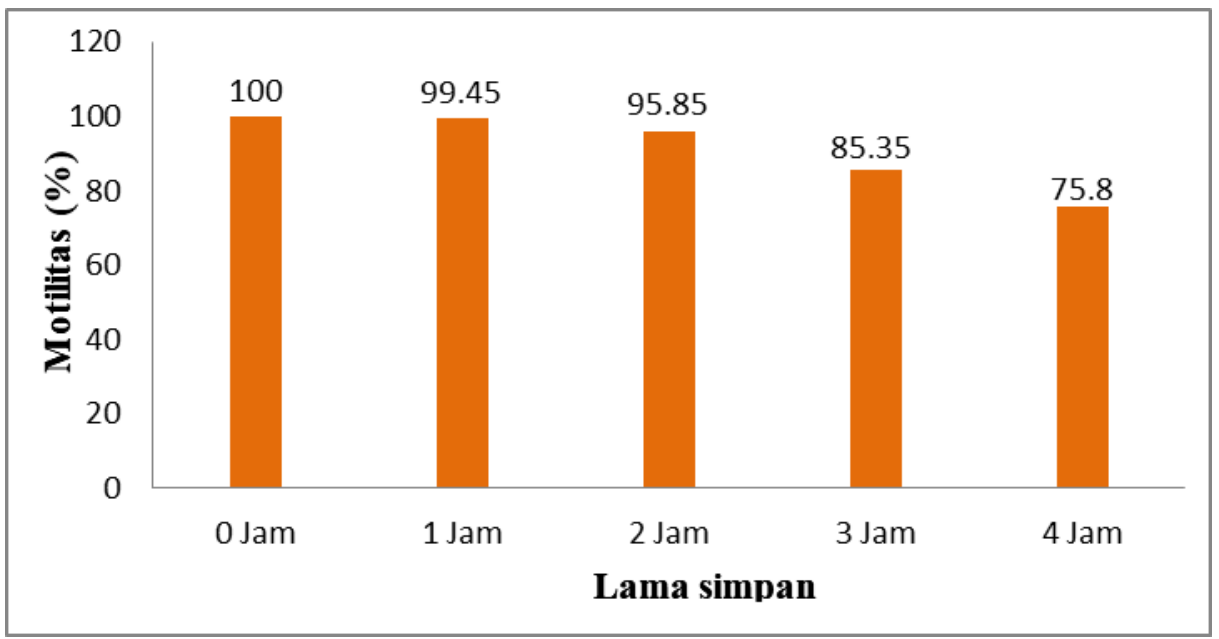

Gambar 2. Grafik motilitas spermatozoa pada suhu ruang dengan lama simpan yang berbeda.

Berdasarkan hasil penelitian spermatozoa ayam Kampung dan ayam Arab menunjukkan tidak terdapat pengaruh yang nyata $(\mathrm{P}<0,05)$ lama simpan $(0,1,2,3$, dan 4 jam) terhadap motilitas spermatozoa pada lama simpan. Motilitas spermatozoa yang masih layak untuk IB sampai lama simpan 4 jam. Hal tersebut sesuai dengan pendapat. Hafez and Hafez (2008) bahwa motilitas standar untuk IB yaitu sebesar minimal $40 \%$.

c. Motilitas spermatozoa pada interaksi jenis semen pada suhu ruang dengan lama simpan yang berbeda

Gambar 3 juga menunjukkan bahwa tidak terdapat interaksi yang nyata $(\mathrm{P}>0,05)$ antara jenis semen pada suhu ruang dan lama simpan yang berbeda.

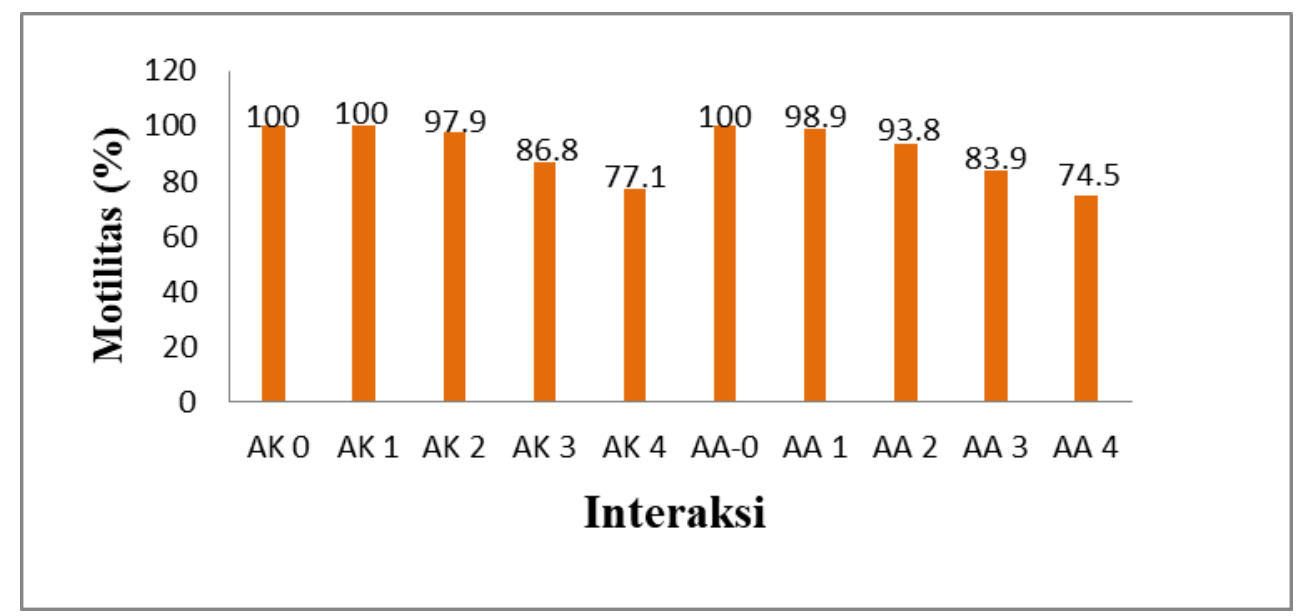

Gambar 3. Grafik motilitas spermatozoa pada interaksi antara jenis semen dan lama simpan yang berbeda.

Berdasarkan analisis motilitas spermatozoa ayam Kampung dan ayam Arab pada suhu ruang dengan lama simpan yang berbeda menunjukkan tidak berpengaruh 


\section{Jurnal Sains Peternakan}

Volume 8 No. 1, Juni 2020, pp:41-56

ISSN 2579-4450

nyata $(\mathrm{P}>0,05)$. Gambar 3. menunjukkan bahwa motilitas ayam Kampung dengan lama simpan 4 jam lebih bagus dibandingkan ayam Arab dengan lama simpan 4 jam. Penurunan motilitas hal tersebut sesuai dengan Solihati $d k k$. (2006), semakin lama waktu penyimpanan semen segar ayam Kampung menyebabkan motilitas spermatozoa terus mengalami penurunan karena persediaan energi semakin terbatas karena selama penyimpanan spermatozoa ini tetap melakukan aktivitas pergerakan dan metabolisme. Hal ini disebabkan karena energi yang digunakan oleh spermatozoa untuk mempertahankan daya hidupnya semakin berkurang. Hal tersebut menyebabkan menurunnya motilitas spermatozoa. Hal tersebut sesuai dengan pendapat.

Pada interaksi ke 0-4 jam menunjukkan bahwa rataan motilitas spermatozoa ayam Kampung dan ayam Arab pada suhu ruang tidak menunjukkan pengaruh nyata terhadap interaksi hal ini sesuai dengan pendapat Hafez (2008) syarat IB minimal motilitas $40 \%$.

\section{Viabilitas}

\section{Viabilitas spermatozoa dengan jenis semen yang berbeda}

Hasil analisa data menunjukkan tidak ada pengaruh yang nyata antarah semen ayam Kampung dan vayam Arab terhadap viabilitas spermatozoa ( $\mathrm{P}>0,05)$. Berdasarkan Gambar 4 menunjukkan rataan persentase viabilitas spermatozoa tertinggi pada semen ayam Kampung yaitu sebesar 91,18\%, dan semen ayam Arab yaitu sebesar $89,94 \%$.

Viabilitas spermatozoa dengan jenis semen yang berbeda di tampilkan pada Gambar 4.

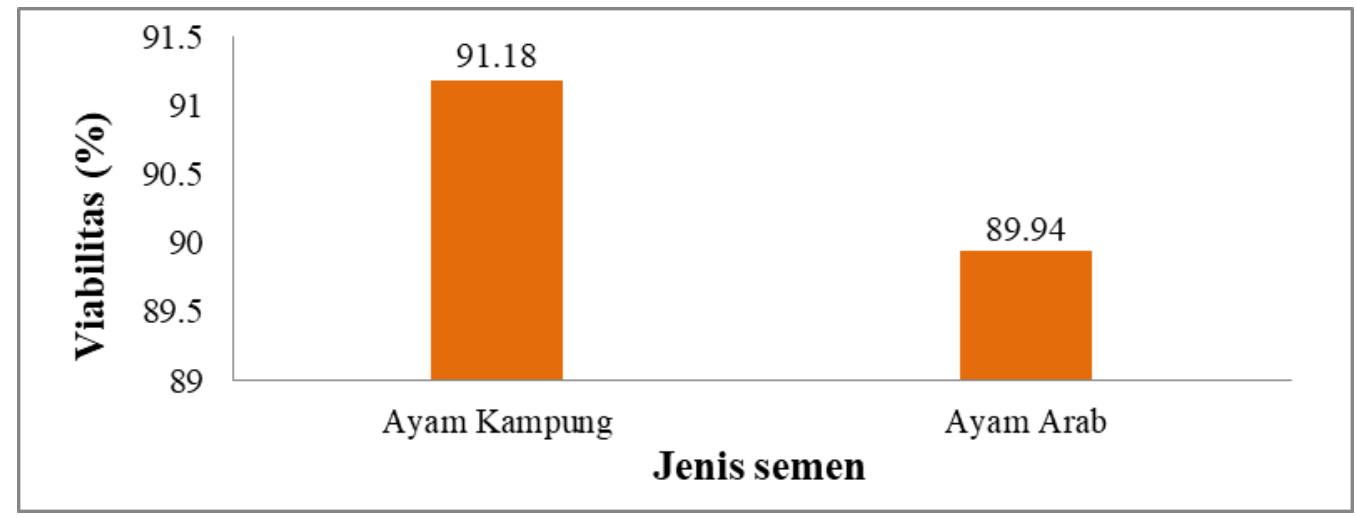

Gambar 4. Grafik viabilitas spermatozoa pada suhu hasil interaksi antara jenis semen dan lama simpan yang berbeda.

Dari grafik jenis semen viabilitas spermatozoa ayam dapat di simpulkan tida ada pengaruh nyata antara spermatozoa ayam Kampung dan spermatozoa ayam 
Arab, tetapi kedua jenis semen tersebut masih memenuhi persyaratan untuk proses IB. Grafik juga menjunjukan semen ayam Kambung lebih dominan dibandingklan ayam Arab, dikarenakan ayam Kampung merupakan ayam lokal atau ayam asli Indonesia dan memiliki daya tahan tubuh yang lebih kuat dibandingkan ayam Arab yang dibawa dari luar Indonesia. Menurut Solihati dkk. (2006), kelebihan ayam Kampung memiliki daya adaptasi tinggi, tahan penyakit tertentu, dan pemeliharaannya mudah. Terjadinya penurunan viabiltas semen dipengaruhi oleh faktor cuaca dan suhu ruang yang tidak stabil. Menurut Solihati dkk. (2006), semakin lama waktu penyimpanan semen segar Ayam Arab menyebabkan motilitas spermatozoa terus mengalami penurunan karena persediaan energi

\section{Viabilitas spermatozoa pada suhu ruang dengan lama simpan yang berbeda}

Hasil analisa data menunjukkan tidak ada pengaruh lama simpan yang nyata terhadap viabilitas spermatozoa $(\mathrm{P}>0,05)$. Berdasarkan Gambar 5 menunjukkan rataan persentase viabilitas spermatozoa tertinggi pada lama simpan ke 0 jam yaitu sebesar $100 \%$ dan untuk viabilitas terendah terjadi pada lama simpan ke 4 jam yaitu $76,25 \%$.

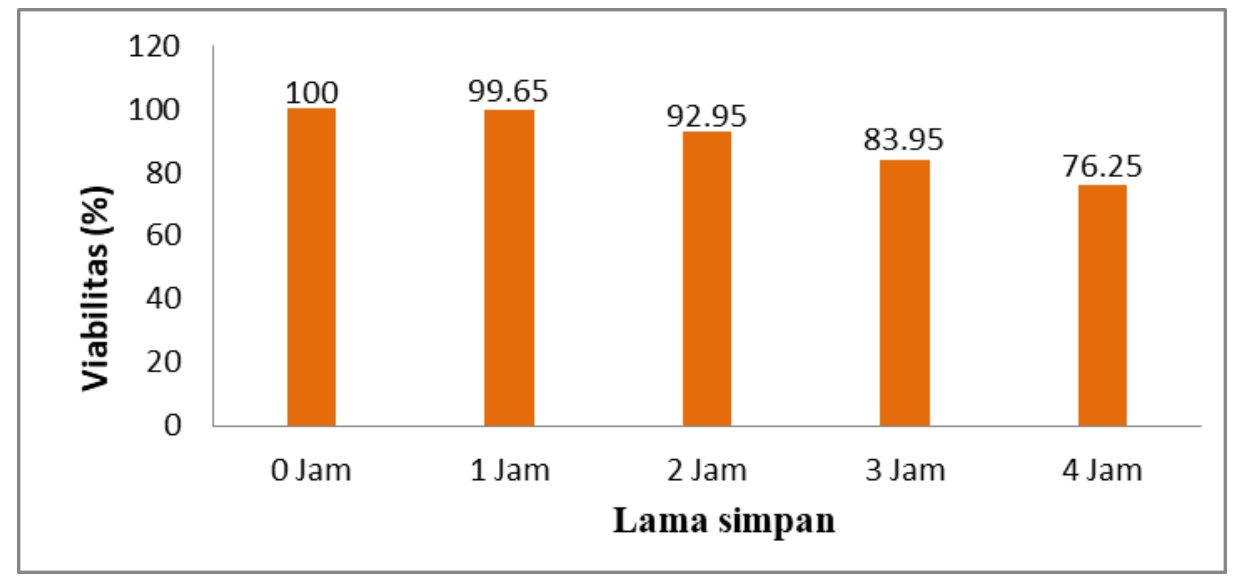

Gambar 5. Grafik viabilitas spermatozoa pada suhu ruang dengan lama simpan yang berbeda.

Berdasarkan analisis pada Gambar 5. Juga menunjukkan bahwa terjadinya penurunan viabilitas semen dari jam ke 0 sampa jam ke 4 yang dipengaruhi oleh lama simpan. Semakin lama waktu simpan maka energi yang dibutuhkan oleh spermatozoa semakin tinggi sehngga banyak spermatozoa yang kehilangan energi. Hal terebut sesuai dengan pendapat Enike dkk (2019) yang menyatakan Semakin lama penyimpanan sperma maka semakin menurun, menurunya kualitas semen 


\section{Jurnal Sains Peternakan}

Volume 8 No. 1, Juni 2020, pp:41-56

ISSN 2579-4450

disebabkan oleh cuaca dan suhu ruang yang kurang stabil. Persentase viabilitas merupakan salah satu indikator untuk menentukan baik-buruknya kualitas semen.

Hal ini disebabkan karena energi yang digunakan oleh spermatozoa untuk mempertahankan daya hidupnya semakin berkurang. Hal tersebut menyebabkan menurunnya viabilitas spermatozoa, hal ini sesuai dengan pendapat, Menurut Hafez (2008) syarat IB minimal motilitas $80 \%$.

Viabilitas spermatozoa pada interaksi jenis semen pada suhu ruang dengan lama simpan yang berbeda.

Gambar 6 menunjukkan bahwa tidak terdapat interaksi yang nyata $(\mathrm{P}>0,05)$ antara jenis semen pada suhu ruang dan lama simpan yang berbeda

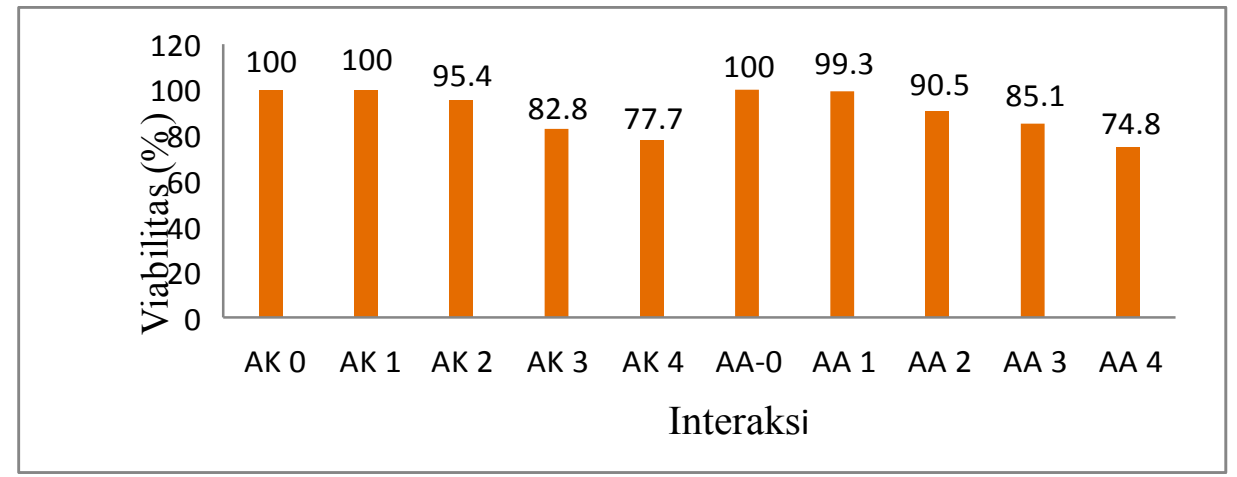

Gambar 6. Grafik viabilitas spermatozoa pada suhu ruang tidak terdapat interaksi nyata antara jenis semen dan lama simpan yang berbeda.

Berdasarkan analisis viabiltas spermatozoa ayam Kampung dan ayam Arab pada suhu ruang dengan lama simpan yang berbeda menunjukkan tidak berpengaruh nyata $(\mathrm{P}<0,05)$. Pada interaksi ke 0-4 jam menunjukkan bahwa rataan viabilitas spermatozoa ayam Kampung dan ayam Arab pada suhu ruang tidak menunjukan pengaruh nyata terhadap interaksi hal ini sesuai dengan pendapat, Menurut Hafez (2008) syarat IB minimal motilitas $80 \%$.

\section{Abnormalitas}

Berdasarkan hasil evaluasi semen Segar ayam Arab seperti terlihat pada Gambar 7. Dapat diketahui bahwa semen dalam penelitian ini mempunyai kualitas yang baik. Hal ini ditunjukkan dengan persentase abnormalitas spermatozoa ayam Kampung sebesar 1,16 dan ayam Arab sebesar 1,6 sehingga semen ini bisa diproses lebih lanjut untuk keperluan IB. Hal ini sesuai dengan pendapat Kartasudjana (2001), semen untuk keperluan inseminsi buatan sebaiknya tidak mengandung sperma abnormal lebih dari $20 \%$. 
Abnomalitas spermatozoa dengan jenis semen yang berbeda pada suhu ruang dengan lama simpan yang berbeda

Hasil analisis presentase abnormalitas spermatozoa ayam Kampung dan ayam Arab menunjukkan bahwa tidak berpengaruh nyata $(\mathrm{P}>0,05)$ terhadap abnormalitas spermatozoa. Abnormalitas spermatozoa ayam Kampung menunjukkan hasil yang lebih baik dibandingkan abnormalitas spermatozoa ayam Arab. Garner dan Hafez (2008) menyatakan bahwa abnormalitas spermatozoa umumnya berkisar antara 1-20\%. Untuk lebih jelasnya dapat dilihat pada Gambar 6. Abnormalitas spermatozoa dengan jenis semen yang berbeda di tampilkan pada Gambar 6.

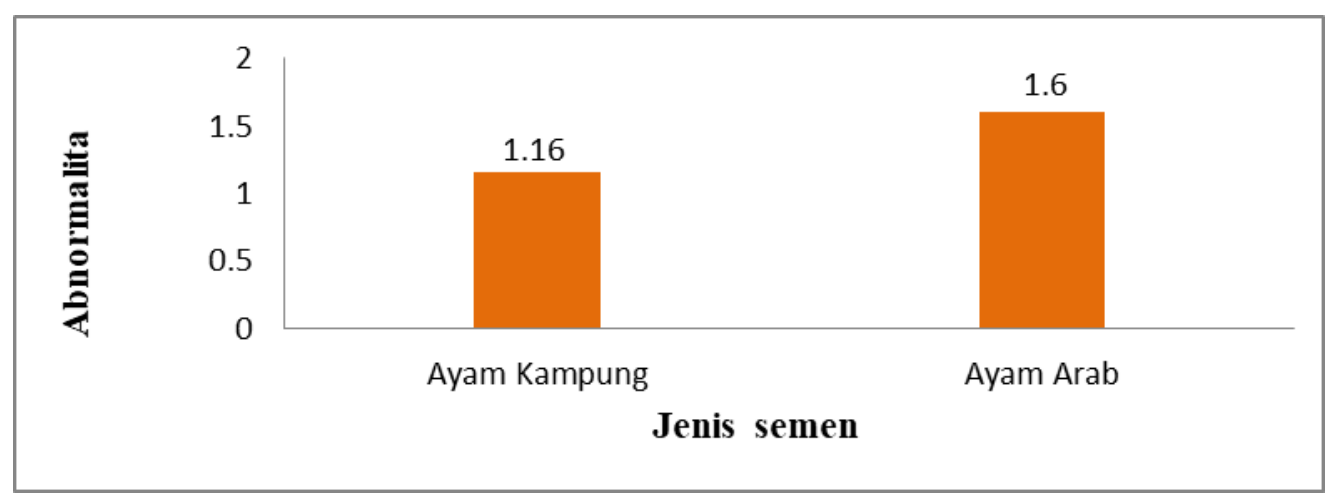

Gambar 6. Grafik abnormalitas spermatozoa dengan jenis semen pada suhu ruang dengan lama simpan yang berbeda.

Dari grafik jenis semen abnormalitas spermatozoa ayam dapat di simpulkan tidak ada pengaruh nyata antara spermatozoa ayam Kampung dan spermatozoa ayam Arab, tetapi masih memenuhu persyaratan untuk proses IB. Grafik juga menjunjukan semen ayam Arab lebih dominan dibandingklan ayam Kampung, Tingginya abnormalitas pada semen ayam Arab dibandingkan ayam Kampung disebabkan karena ayam Kampung memiliki daya adaptasi tinggi dan tahan terhadap penyakit. Hal terebut sesuai dengan pendapat Enike dkk (2019) yang menyatakan Semakin lama penyimpanan sperma maka semakin menurun, menurunya kualitas semen disebabkan oleh cuaca dan suhu ruang yang kurang stabil. Sesuai pernyataan Rizal dan Herdis (2006) bahwa abnormalitas lebih banyak berupa terpisahnya ekor dengan kepala akibat terputus saat pembuatan preparat sebelum dilakukan pengamatan.

\section{Abnormalitas spermatozoa pada suhu ruang dengan lama simpan yang berbeda.}

Hasil penelitian semen segar ayam Kampung dan ayam Arab dengan lama simpan yang berbeda pada suhu ruang menunjukkan rataan persentase 


\section{Jurnal Sains Peternakan}

Volume 8 No. 1, Juni 2020, pp:41-56

ISSN 2579-4450

abnormalitas spermatozoa tertinggi pada lama simpan ke 4 jam yaitu sebesar 2,8\%, dan untuk abnormaitas terendah terjadi pada lama simpan ke 0 jam yaitu $0,35 \%$, Untuk lebih jelas lihat pada Gambar 7 berikut ini.

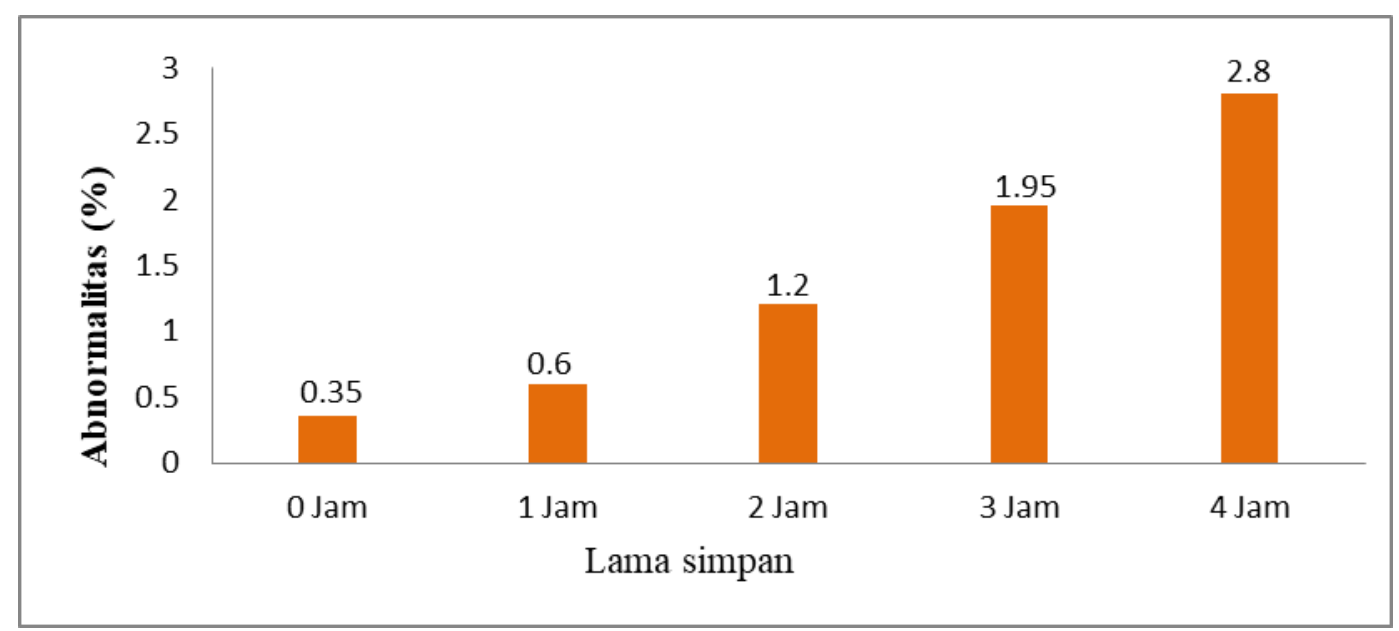

Gambar 7. Grafik abnormalitas spermatozoa pada suhu ruang dengan lama simpan yang berbeda.

Berdasarkan analisis data di atas menunjukkan bahwa abnormalitas spermatozoa ayam Arab pada suhu ruang dengan lama simpan yang berbeda menunjukkan tidak berpengaruh nyata $(\mathrm{P}>0,05)$. Perlakuan pada lama simpan 0 , $1,2,3$, dan 4 jam rataan abnormalitas berkisar antara $0,35-2,8 \%$ yang masih berada dalam kisaran standar minimum untuk program IB. Menurut Pineda (2003) standar abnormalitas untuk IB maksimal sebesar 20\%.

\section{Abnomalitas spermatozoa pada interaksi jenis semen pada suhu ruang dengan lama simpan yang berbeda}

Berdasarkan hasil analisa data interaksi tidak berpengaruh nyata. Antara jenis semen dan lama simpan $(\mathrm{P}<0,05)$ terhadap abnormalitas seperti pada. Gambar 8.

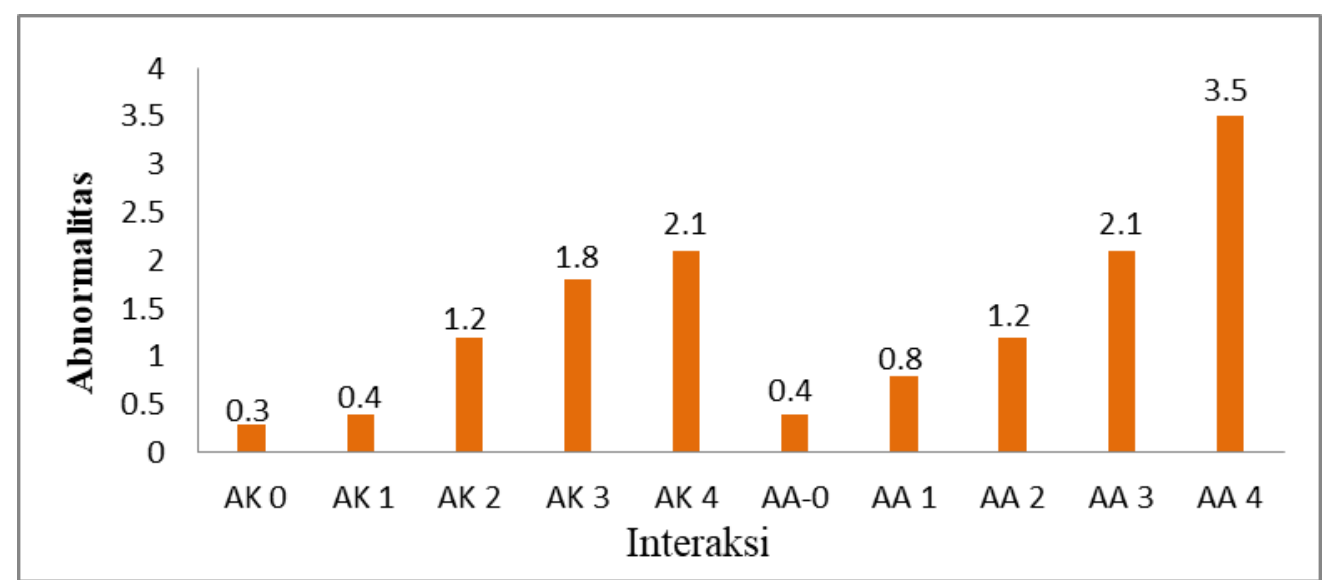

Gambar 8. Grafik abnormalitas spermatozoa pada suhu ruang tidak terdapat interaksi nyata antara jenis semen dan lama simpan yang berbeda. 
Berdasarkan analisis abnormalitas spermatozoa ayam Kampung dan ayam Arab pada suhu ruang dengan lama simpan yang berbeda menunjukkan tidak berpengaruh sangat nyata $(\mathrm{P}<0,05)$. Pada interaksi dari 0-4 jam menunjukkan bahwa rataan interaksi spermatozoa ayam Kampung sebesar $0,3 \pm 2,1$ dan ayam Arab sebesar $0,4 \pm 3,5$ pada suhu ruang masih berada dalam kisaran standar minimum untuk program IB tdak lebih dari $15-20 \%$. Walaupun mengalami peningkatan tetapi rataan persentase abnormalitas tidak lebih dari 15\%. Hal ini sesuai pendapat Kartasudjana (2001) bahwa sebaiknya semen yang digunakan untuk diperlukan untuk IB tidak mengandung sperma abnormal lebih dari $20 \%$.

\section{Kesimpulan}

Berdasarkan hasil penelitian dapat disimpulkan bahwa kualitas semen ayam Kampung dan ayam Arab yang meliputi motilitas, viabilitas dan abnormalitas spermatozoa dapat dipertahankan sampai batas optimum untuk IB dengan dengan lama simpan 3 jam pada suhu ruang dan tidak terdapat pengaruh nyata terhadap semen ayam Kampung dan semen ayam Arab.

\section{Daftar Rujukan}

Darwati. 2000. Produktivitas Ayam Kampung, Pelung dan Resiprokalnya. Jurnal Penelitian IPB.

Hafez, ESE. 2008. Anatomy of female reproduction. Ed pp. 29-55.

Iskandar, S 2006. Ayam silangan dana rap. Tingkat protein pakan untuk produksi daging umur 12 minggu, Wartozoa 16 (2): 65-71.

Junaedi, R.I. Arifiantini, C. Sumantridan A. Gunawan. 2016. Penggunaan Dimethyl Sulfoxide sebagai Kriopretektan dalam Pembekuan Semen Ayam Kampung. Jurnal Veteriner, 17(2):300-308.

Kartasudjana, R. 2001. Teknik Inseminasi Buatan pada Ternak.Modul Program Keahlian Budidaya Ternak.Depertemen Pendidikan Nasional.Proyek Pengembangan Sistem dan Standar Pengelolaan SMK. Direktorat Pendidikan Menengah Kejuruan. Jakarta.

Khairi, F., A. Muktiani dan Y. S. Ondho. 2014. Pengaruh Suplementasi Vitamin E, Mineral Selinium Dan Zink Terhadap Konsumsi Nutrien, Produksi Dan Kualitas Semen Sapi Simental. Agrepet. 14(1):6-16

Lubis, T.M, Dasrul, Hamdan dan Fauziah. 2012. Efek Suplementasi Enervon-C dan Santa-e dalam Pakan terhadap Motilitas Spermatozoa Ayam Kampung. Jurnal Agripet, 12(1):34-40. 


\section{Jurnal Sains Peternakan}

Volume 8 No. 1, Juni 2020, pp:41-56

ISSN 2579-4450

Natamijaya, A.G, A.R. Setioko, B. Brahmantiyo dan K. Diwyanto. 2003. Performans dan Karakteristik Tiga GalurAyam Lokal (Pelung, Arab dan Sentul). Seminar Nasional Teknologi Peternakan dan Veteriner. Pusat Penelitian dan Pengembangan Peternakan. Bogor.

Rusdin. (2006). Pasar Modal: Teori, Masalah, dan Kebijakan Dalam Praktik. Bandung: Alfabeta.

Selvinus L. W., Kusumawati, E. D., dan Krisnaningsih, A. T. N. 2017. Motilitas dan Viabilitas Spermatozoa Ayam Kampung Pada Suhu 5C Mengunakan Pengencer dan Lama Simpan yang Berbeda.Skripsi. Fakultas Peternakan. Universitas Kanjuruhan Malang

Solihati N, Ruhijat 1, Setiawan R, Asmara IY, Sujana BI. 2006. Pengaruh lama penyimpanan spermatozoa cair Ayam Buras pada suhu $5{ }^{\circ} \mathrm{c}$ terhadap periode fertil dan fertilisasa sperma. Jurnal Ilmu Ternak 6: $7^{-11}$. 